\title{
Serine 68 Phospholemman Phosphorylation during Forskolin-Induced Swine Carotid Artery Relaxation
}

\author{
Christopher M. Rembold ${ }^{a-c}$ Marcia L. Ripley ${ }^{a}$ Melissa K. Meeks ${ }^{a}$ \\ Lisa M. Geddis ${ }^{c}$ Howard C. Kutchai $^{c}$ Francesca M. Marassi $^{d}$ \\ Joseph Y. Cheung ${ }^{\mathrm{e}}$ J. Randall Moorman ${ }^{\mathrm{a}, \mathrm{b}}$ \\ ${ }^{a}$ Cardiovascular Division, Department of Internal Medicine, ${ }^{b}$ Cardiovascular Research Center, \\ ${ }^{c}$ Department of Molecular Physiology and Biological Physics, University of Virginia Health System, \\ Charlottesville, Va., ${ }^{\mathrm{d}}$ The Burnham Institute, La Jolla, Calif., and ${ }^{\mathrm{e}}$ Department of Cellular and \\ Molecular Physiology, Pennsylvania State University College of Medicine, Hershey, Pa., USA
}

\section{Key Words}

Cyclic adenosine monophosphate $\cdot$ FXYD protein •

Phospholemman · Phosphorylation · Vascular smooth muscle

\begin{abstract}
Background: Phospholemman (PLM) is an abundant phosphoprotein in the plasma membrane of cardiac, skeletal and smooth muscle. It is a member of the FXYD family of proteins that bind to and regulate the $\mathrm{Na}, \mathrm{K}$ ATPase. Protein kinase A (PKA) is known to phosphorylate PLM on serine 68 (S68), although the functional effect of S68 PLM phosphorylation is unclear. We therefore evaluated S68 PLM phosphorylation in swine carotid arteries. Methods: Two anti-PLM antibodies, one to S68 phosphorylated PLM and one to unphosphorylated PLM, were made to PLM peptides in rabbits and tested with purified PLM and PKA-treated PLM. Swine carotid arteries were mounted isometrically, contracted, relaxed with forskolin and then homogenized. Proteins were separated on SDS gels and the intensity of immunoreactivity to the two PLM antibodies determined on immunoblots. Results: The antipeptide antibody ' $\mathrm{C} 2$ ' primarily reacted with unphosphorylated PLM, and the antipeptide anti-
\end{abstract}

body 'CP68' detected S68 PLM phosphorylation. Histamine stimulation of intact swine carotid artery induced a contraction, increased the CP68 PLM antibody signal and reduced the C2 PLM antibody signal. High extracellular $\left[\mathrm{K}^{+}\right]$depolarization induced a contraction without altering the C2 or CP68 PLM signal. Forskolin-induced relaxation of histamine or extracellular $\left[\mathrm{K}^{+}\right]$contracted arteries correlated with an increased CP68 signal. Nitroglycerin-induced relaxation was not associated with changes in the C2 or CP68 PLM signal. Conclusions: These data suggest that a contractile agonist increased S68 PLM phosphorylation. Agents that increase [CAMP], but not agents that increase [cGMP], increased S68 PLM phosphorylation. S68 PLM phosphorylation may be involved in cAMP-dependent regulation of smooth muscle force.

Copyright (C) 2005 S. Karger AG, Basel

\section{Introduction}

Phospholemman (PLM, also known as FXYD1) is a 72-amino acid sarcolemmal protein that is abundant in heart and skeletal muscle and present in other tissues such as kidney [1]. Protein kinase A (PKA) induces PLM phos-

\section{KARGER}

(C) 2005 S. Karger AG, Basel

Fax +41613061234 E-Mail karger@karger.ch www.karger.com www.karger.com/jvr
Christopher M. Rembold, MD

Cardiovascular Division, Box 801395

University of Virginia Health System

Charlottesville, VA 22908-1395 (USA)

Tel. +1 434924 2825, Fax +1 434982 3162, E-Mail crembold@virginia.edu 
phorylation on serine 68 (S68) $[2,3]$ while protein kinase $\mathrm{C}$ (PKC) induces phosphorylation on both serine 63 (S63) and S68 [2, 3]. Initial studies suggested a role for PLM in osmolyte flux and cell volume regulation $[4,5]$. More recent findings suggest a physical and functional association of PLM with membrane ion transporters such as the $\mathrm{Na}, \mathrm{K}-\mathrm{ATP}$ ase $[6,7]$ and the Na-Ca exchanger (NCX1) $[8,9]$. These findings suggest that PLM may have functional roles similar to other members of the FXYD family of proteins [10]. For example, the $\gamma$-subunit of $\mathrm{Na}, \mathrm{K}$ ATPase (FXYD2) shares significant homology with PLM [10] that could explain the effect of PLM on Na,K-ATPase activity [11].

Very little is known about PLM in smooth muscle. Three papers describe a 16 - to $17-\mathrm{kDa}$ phosphoprotein in smooth muscle that may well have been PLM (PLM has an apparent molecular weight of approximately $16 \mathrm{kDa}$ on SDS gels) [1]. In 1985, Boulanger-Saunier et al. [12] identified a $16-\mathrm{kDa}$ phosphoprotein in a plasma membrane-enriched fraction of rat aortic smooth muscle cell membranes. This protein copurified with $\mathrm{Na}$,K-ATPase and was phosphorylated by PKA in vitro and by isoproterenol in vivo. Its dephosphorylation was inhibited by $10 \mathrm{~m} M \mathrm{NaF}$. Boulanger-Saunier et al. [13] subsequently found that a phorbol ester (TPA) in vitro and arginine vasopressin in vivo induced phosphorylation of the 16-kDa protein on a second site distinct from the PKA site. In 1989, Sarevic et al. [14] found that a 17-kDa membrane phosphoprotein, likely PLM, was phosphorylated by PKA but not by protein kinase G. PLM mRNA has been reported in canine aortic, esophageal and gastric smooth muscle [1]. While these publications suggest that PLM is present and phosphorylated in intact smooth muscle, they cannot be considered definitive as they predate the cloning of PLM in 1991 and the subsequent development of reagents to study it.

Contraction of smooth muscle is typically associated with increased intracellular $\left[\mathrm{Ca}^{2+}\right]\left(\left[\mathrm{Ca}^{2+}\right]_{\mathrm{i}}\right)$, formation of a $\mathrm{Ca}^{2+}{ }_{4}$-calmodulin complex, activation of myosin light chain kinase (MLCK) and phosphorylation of myosin regulatory light chains (MRLC) on serine 19 [15]. Phosphorylation of MRLC enables crossbridge attachment to the thin filament, thereby allowing crossbridge cycling and force generation [16]. In many cases, smooth muscle relaxation proceeds via a reversal of this contraction process: reduction of myoplasmic $\left[\mathrm{Ca}^{2+}\right]$, inactivation of MLCK and dephosphorylation of MRLC [17-19].

cAMP-mediated smooth muscle relaxation occurs via binding of agonists to specific seven-membrane-spanning receptors (e.g., $\beta_{2}$-adrenergic) which activate adenylyl cy- clase via $\mathrm{G}$ proteins [e.g., ref. 20]. Adenylyl cyclase can also be directly and relatively specifically activated by low concentrations of forskolin (e.g., $0.1-1 \mu M)$. It is well known that increases in $[\mathrm{cAMP}]$ can reduce $\left[\mathrm{Ca}^{2+}\right]_{\mathrm{i}}$ and thereby inactivate MLCK and cause relaxation by MRLC dephosphorylation [see reviews in ref. 21, 22]. Specific mechanisms for reduction in $\left[\mathrm{Ca}^{2+}\right]_{\mathrm{i}}$ include (1) inhibition of $\mathrm{Ca}^{2+}$ mobilization from the sarcoplasmic reticulum [21], (2) hyperpolarization [23], (3) decreased $\mathrm{Ca}^{2+}$ influx through voltage-gated channels [24], and (4) activation of plasma membrane $\mathrm{Ca}^{2+}$ pumps [25]. There are also mechanisms other than reductions in $\left[\mathrm{Ca}^{2+}\right]_{\mathrm{i}}$ where increased [cAMP] can cause relaxation, e.g., force suppression associated with serine 16 heat shock protein 20 phosphorylation [26].

Our general hypothesis is that cAMP-mediated phosphorylation of PLM on S68 phosphorylation causes vascular smooth muscle relaxation by increasing the activity of the Na,K-ATPase. The goals of this study were (1) to determine if PLM is present in smooth muscle, (2) to determine if cAMP-mediated relaxation is associated with S68 PLM phosphorylation, the site phosphorylated by PKA in vitro, and (3) to infer whether cAMP-mediated relaxation is associated with a decrease in intracellular $\mathrm{Na}^{+}\left(\left[\mathrm{Na}^{+}\right]_{\mathrm{i}}\right)$. To accomplish these goals, we developed S68 phosphorylation-specific PLM antibodies. These antibodies were then tested in forskolin-induced relaxation of swine carotid artery.

\section{Material and Methods}

\section{Tissues}

Swine common carotid arteries were obtained from a slaughterhouse and transported at $0^{\circ} \mathrm{C}$ in physiological salt solution (PSS). PSS contained (mM): $\mathrm{NaCl} 140, \mathrm{KCl} 4.7,3$-[N-morpholino] propane sulfonic acid 5, $\mathrm{Na}_{2} \mathrm{HPO}_{4} 1.2, \mathrm{CaCl}_{2} 1.6, \mathrm{MgSO}_{4}$ 1.2, $D$-glucose 5.6, pH adjusted to 7.4 at $37^{\circ} \mathrm{C}$. Zero $\mathrm{Na}^{+}$PSS was PSS where CholineCl was substituted for $\mathrm{NaCl}$ and the $\mathrm{Na}_{2} \mathrm{HPO}_{4}$ was omitted. Dissection of medial strips, mounting and determination of the optimum length for stress development at $37^{\circ} \mathrm{C}$ were performed as previously described [27]. The intimal surface was mechanically rubbed to remove the endothelium.

\section{Antibodies}

We developed two specific antibodies against PLM: C2 which was made to react with dephosphorylated PLM and CP68 which was made to react with PLM phosphorylated at S68, the site phosphorylated by PKA. Both were raised against C-terminal PLM peptides. To raise polyclonal antibodies against dephosphorylated PLM (C2), the 16-amino acid peptide $\mathrm{NH}_{2}$-CGTFRSSIRRLSTR $\mathrm{RR}-\mathrm{COOH}$ was used as the antigen and the resulting rabbit polyclonal antibody affinity purified as described [28]. To make S68 phosphorylation-specific antibodies (CP68), the 19-amino acid 
peptide $\mathrm{NH}_{2}$-DEEEGTFRSSIRRL Sp (68) TRRR-COOH was made with phosphoserine ( $\mathrm{Sp}$ ) at $\mathrm{S} 68$. This peptide was injected into rabbits and serum collected. For affinity purification of CP68 (the phosphorylation-specific antibody), the serum was processed over an agarose immunosorbent containing the unconjugated dephosphorylated peptide to remove antibody activity that would bind the peptide irrespective of phosphorylation status. Phosphorylated PLM-specific antibodies were then affinity purified from the cleaned serum by passage over an immunosorbent containing the phosphorylated PLM peptide. ELISA showed less than $2 \%$ cross reactivity of the phosphorylated PLM-specific antibody with the dephosphorylated PLM peptide (Bethyl Labs, Montgomery, Tex., USA).

\section{PLM Standards}

Purified recombinant dephosphorylated PLM was prepared as described [29]. A pig cardiac sarcolemmal vesicle preparation [30] was loaded on most blots since it contained dephosphorylated and phosphorylated PLM that was detected by both anti-PLM antibodies.

\section{PLM in vitro Phosphorylation}

Forty micrograms of purified recombinant dephosphorylated PLM (trifluorethanol removed by $\mathrm{N}_{2}$ evaporation) [29] were incubated in $200 \mu \mathrm{l}$ of a buffer containing $50 \mathrm{~m} M$ HEPES $(\mathrm{pH} 7.5)$, $10 \mathrm{~m} M \mathrm{MgCl}_{2}, 1 \mathrm{~m} M$ EGTA, $0.1 \%$ Triton X-100, $25 \mathrm{~m} M \mathrm{NaF}$ and $0.1 \mathrm{~m} M$ ATP with $\gamma-{ }^{32} \mathrm{P}$-ATP. Samples were removed both before and after addition of $1 \mu \mathrm{l}(1.1 \mu \mathrm{g})$ of the catalytic subunit of PKA (specific activity $6.3 \mu \mathrm{mol} / \mathrm{min} / \mathrm{mg}$, a generous gift of Tom Lincoln, $\mathrm{PhD}$ ). The reaction was stopped by addition of $1 \%$ SDS. The stoichiometry of PLM phosphorylation was calculated from the ${ }^{32} \mathrm{P}$ activity of the phosphorylated PLM (dpm/mol PLM) divided by the ${ }^{32} \mathrm{P}$-specific activity of the ATP employed (dpm/mol $\gamma$-phosphate in ATP).

\section{Measurement of PLM Phosphorylation}

Swine carotid arteries were pharmacologically treated and frozen in an acetone-dry ice slurry $(20 \mathrm{~g} / 20 \mathrm{ml})$ at $-78^{\circ} \mathrm{C}$ [27]. The frozen tissue was allowed to slowly thaw to room temperature in the slurry $(2 \mathrm{~h})$, the tissues were air dried, weighed and homogenized in a buffer containing 1\% SDS, 10\% glycerol and $20 \mathrm{mM}$ dithiothreitol (20 mg wet weight/ml buffer). Twenty microliters of homogenates (concentration normalized to tissue weight) were then loaded identically onto two $12 \%$ SDS electrophoresis gels, blotted to nitrocellulose and then incubated with the anti-PLM antibodies (1:10,000 for C2 and 1:1,000 for CP68). After washing, incubation with secondary antibodies (1:5,000 of goat anti-rabbit) and detection with enhanced chemiluminescence, the blots were imaged and digitized with UnScanIt (Silk Scientific Inc.).

Two internal standards were loaded on every gel to allow comparison of immunoblotting intensity on different blots. One standard, 'KF', was a pooled homogenate of swine carotid tissues that had been activated with $109 \mathrm{~m} M$ extracellular $\left[\mathrm{K}^{+}\right]\left(\left[\mathrm{K}^{+}\right]_{\mathrm{o}}\right)$ for $10 \mathrm{~min}$ followed by the addition of $10 \mu \mathrm{M}$ forskolin for $30 \mathrm{~min}$. The second standard, ' $K$ ', was a pooled homogenate of swine carotid tissues that had been activated with $109 \mathrm{mM}\left[\mathrm{K}^{+}\right]_{\mathrm{o}}$ for $40 \mathrm{~min}$. The intensity of the PLM antibody immunoreactivity was determined for the experimental samples and these standards on every blot. We found that the ratio of the intensity of experimental sample CP68 immunoblotting to the intensity of KF immunoblotting from the same blot was the most reproducible for CP68 (similar results were seen with other normalizations); therefore, we report the CP68/KF ratio as an index of S68-PLM phosphorylation (fig. 3b, d). We found that the $\mathrm{C} 2$ blots were most reproducible when the intensity of sample $\mathrm{C} 2$ immunoblotting was normalized to the intensity of the $\mathrm{C} 2$ immunoblotting from the unstimulated control swine carotid artery tissue from the same blot; therefore, we report the $\mathrm{C} 2$ / control ratio as an index of unphosphorylated PLM (fig. 3a, c).

\section{Statistics}

The significance of the correlation between the intensity of CP68 immunoblotting and contractile force shown in figure 4 was tested using analysis of covariance (ANCOVA). The analysis showed no significant difference among the slopes for different experimental conditions, so the final model allowed intercepts but not slopes to vary. Significance was defined as $\mathrm{p}<0.05$.

\section{Results}

As detailed in the methods, two antibodies were made to C-terminal PLM peptides. To evaluate the specificity of these antibodies, purified recombinant PLM [29] (shown to be dephosphorylated by mass spectrometry) was phosphorylated with the catalytic subunit of PKA in the presence of $\gamma_{-}{ }^{32} \mathrm{P}$-ATP. Different amounts of phosphorylated and dephosphorylated PLM (exposed to $\gamma_{-}{ }^{32}$ P-ATP without PKA) were loaded on SDS gels, blotted, analyzed for ${ }^{32} \mathrm{P}$ activity and immunoblotted with both antibodies. Increasing ${ }^{32} \mathrm{P}$ activity was observed with an increasing amount of PKA-treated PLM (fig. 1, top panel). Calculated stoichiometry revealed that approximately $50 \%$ of PLM was phosphorylated by PKA treatment (a time course suggested we had reached steadystate phosphorylation). Dephosphorylated PLM was not detected by the CP68 antibody (fig. 1, second panel). The intensity of the CP68 antibody signal was proportional to the amount of PKA-treated PLM loaded on the immunoblot (fig. 1, third panel). The intensity of the $\mathrm{C} 2$ antibody signal was proportional to the amount of dephosphorylated PLM loaded on the immunoblot (fig. 1, fourth panel). The intensity of the $\mathrm{C} 2$ antibody signal was less intense on immunoblots loaded with PKA-treated PLM (fig. 1, bottom panel) compared with that observed with dephosphorylated PLM.

Swine carotid medial smooth muscle rings were first equilibrated and then contracted with $10 \mu M$ histamine or $40 \mathrm{mM}\left[\mathrm{K}^{+}\right]_{0}$ for $10 \mathrm{~min}$. Some were then relaxed with $0.1,0.3,1,3$ or $10 \mu M$ forskolin, and others were left in the contraction solution. After an additional $30 \mathrm{~min}$, tissues were frozen and homogenized. Proteins were separated on SDS gels and the intensity of immunoreactiv- 


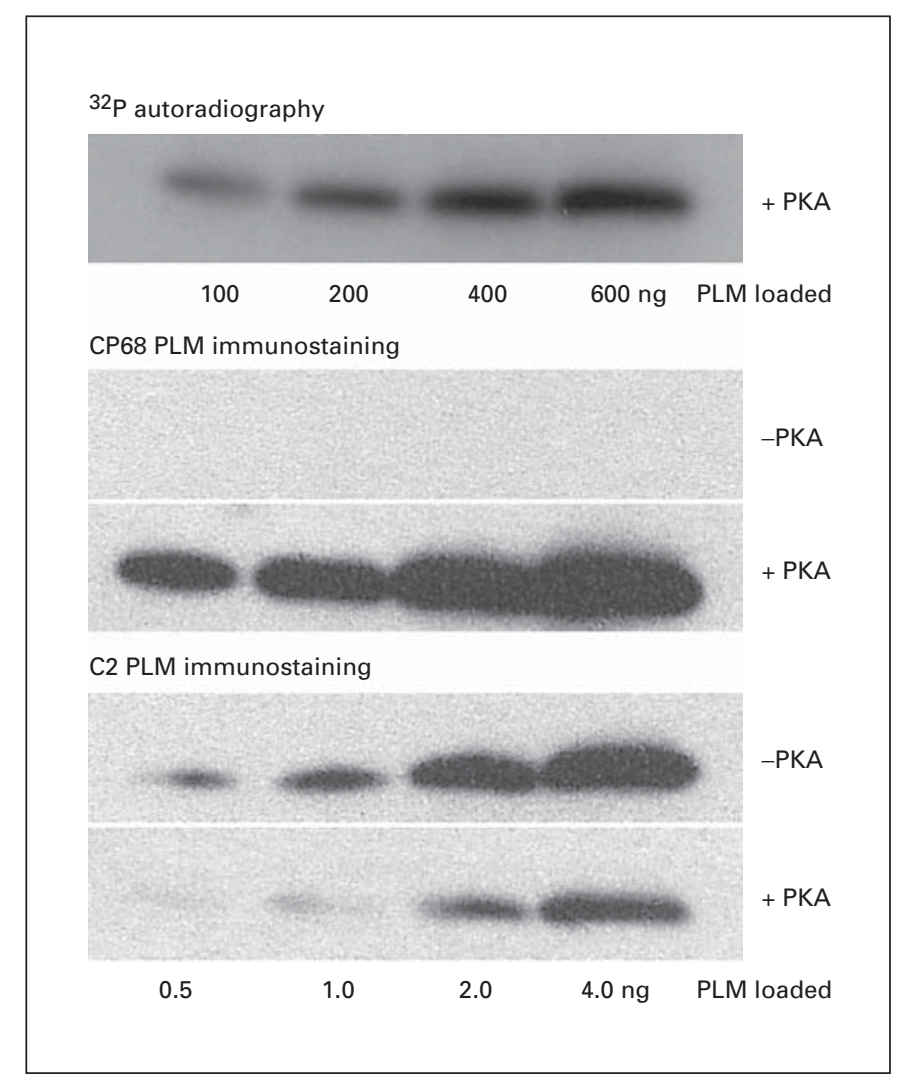

Fig. 1. Specificity of the anti-PLM antibodies. Purified recombinant PLM was either phosphorylated with or without PKA in the presence of $\gamma-{ }^{32} \mathrm{P}-\mathrm{ATP}$ and then run on SDS gel electrophoresis. The top panel shows an autoradiogram of PLM treated with PKA (there was no ${ }^{32} \mathrm{P}$ activity in PLM exposed to $\gamma-{ }^{32} \mathrm{P}-\mathrm{ATP}$ without PKA). The second panel shows an immunoblot of untreated PLM with the CP68 antibody. The third panel shows an immunoblot of PLM treated with PKA with the CP68 antibody. The fourth panel shows an immunoblot of untreated PLM with the $\mathrm{C} 2$ antibody. The fifth panel shows an immunoblot of PLM treated with PKA with the $\mathrm{C} 2$ antibody.

ity to the two PLM antibodies determined on immunoblots. As detailed in 'Material and Methods', the intensity of both the $\mathrm{C} 2$ and CP68 antibodies were normalized to internal standards. For clarity, the term ' $\mathrm{C} 2$ signal' will refer to the intensity of the $\mathrm{C} 2$ antibody immunoreactivity normalized to the intensity of the $\mathrm{C} 2$ antibody immunoreactivity from the untreated control tissue homogenate loaded on the same blot. Similarly, the term 'CP68 signal' will refer to the intensity of the CP68 antibody immunoreactivity normalized to the intensity of the CP68 antibody immunoreactivity from the KF pooled homogenate loaded on the same blot.

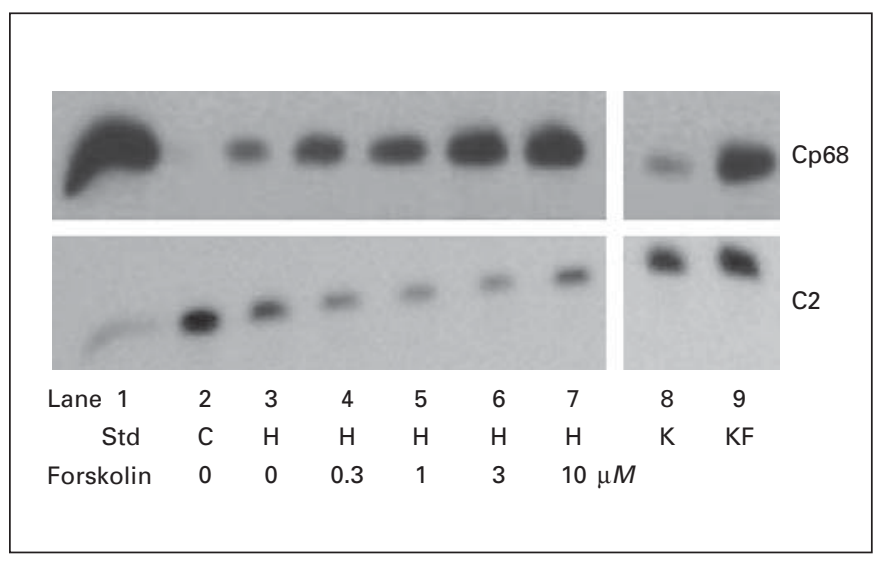

Fig. 2. Changes in the CP68 (top panel) and C2 (bottom panel) PLM signals in swine carotid artery tissue homogenates. Lane 1 is the heart sarcolemmal PLM standard that is detected by all antibodies. Lane 2 is from unstimulated swine carotid tissues, i.e. the control (which is used to normalize the $\mathrm{C} 2$ signals in figure 3 as detailed in 'Material and Methods'). Lane 3 is from $10 \mu M$ histamine-stimulated tissues. Lanes 4-7 are from tissues first stimulated with $10 \mu M$ histamine followed by addition of $0.3,1,3$ or $10 \mu M$ forskolin to induce relaxation. Lanes 8 and 9 are the $\mathrm{K}$ and $\mathrm{KF}$ standards (Std) (see 'Material and Methods').

This normalization procedure allows comparison of changes in the C2 and CP68 antibody intensity on different immunoblots. Figure 2 shows a representative immunoblot of tissues stimulated with histamine, and figure 3 shows aggregate data. PLM was present in swine arterial smooth muscle, and its phosphorylation status depended on the treatment.

Unstimulated (control) tissues had low levels of CP68 signal and force (fig. 2, lane 2; fig. 3, filled symbols). Histamine $(10 \mu M)$ induced a large decrease in the $\mathrm{C} 2$ signal, a small increase in the CP68 signal and a maximal contraction (fig. 2, lane 3; fig. 3, open squares). Adding forskolin to histamine-stimulated tissues was associated with no change in the $\mathrm{C} 2$ signal, dose-dependent increases in the CP68 signal (fig. 2, lanes 4-7) and dose-dependent reduction in force (fig. 3 ).

Forty millimoles $\left[\mathrm{K}^{+}\right]_{0}$ depolarization induced a maximal contraction without significant changes in the $\mathrm{C} 2$ or CP68 signal (fig. 3, open circles). Adding forskolin to high $\left[\mathrm{K}^{+}\right]_{0}$-depolarized tissues was associated with a reduced C2 signal, dose-dependent increases in the CP68 signal and dose-dependent reduction in force. When relaxed with forskolin, the histamine-stimulated tissues exhibited a greater CP68 signal and lower force than that observed in the $40 \mathrm{mM}\left[\mathrm{K}^{+}\right]_{0}$-depolarized tissues. 


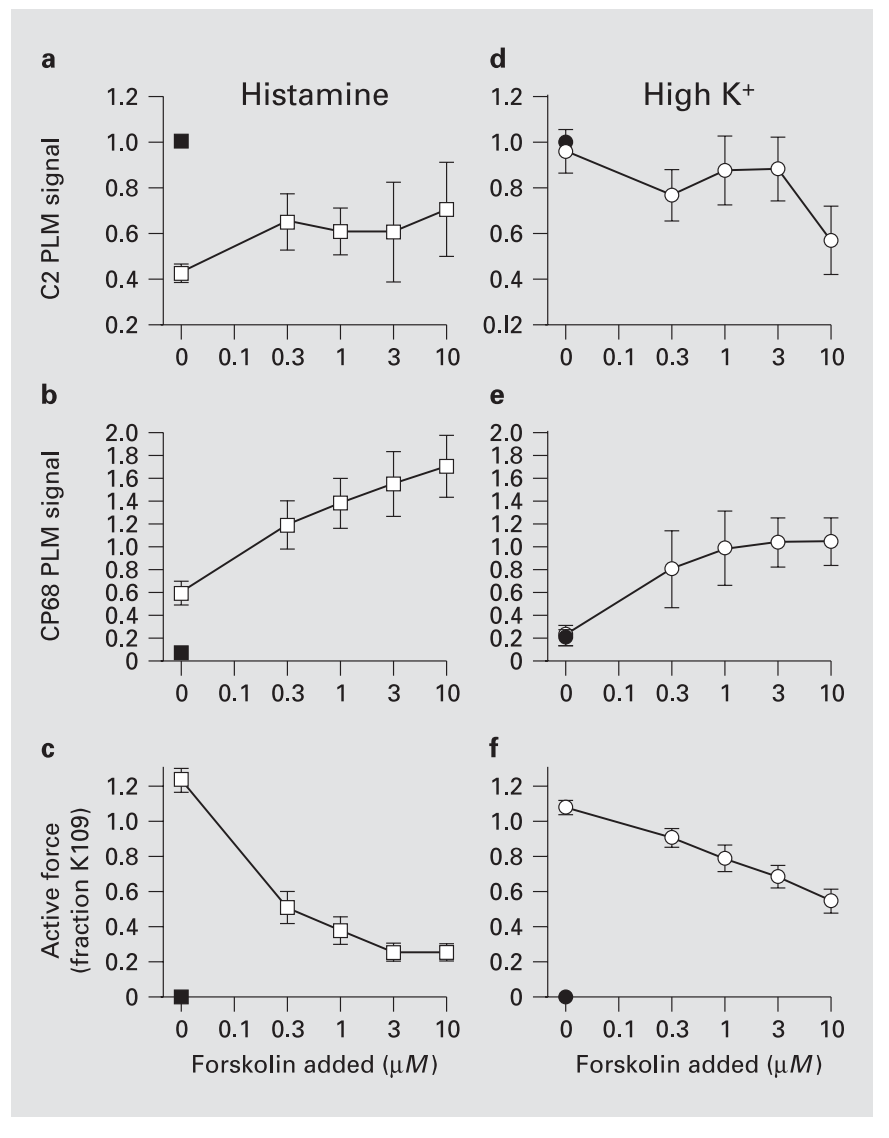

Fig. 3. Biochemical events occurring in forskolin relaxed swine carotid artery activated by histamine $(\mathbf{a}-\mathbf{c})$ or high $\left[\mathrm{K}^{+}\right]_{\mathrm{o}}$ depolarization (d-f). Immunoblot intensity was normalized as described in 'Material and Methods' and is presented as mean \pm 1 SEM with $n=4-5$. Tissues were activated with $10 \mu M$ histamine $(\square)$ or $40 \mathrm{mM}\left[\mathrm{K}^{+}\right]_{0}$ (O) and then relaxed by addition of various [forskolin] as described on the abscissa. Unstimulated control tissues are shown as $\mathbf{\square}$ or $\boldsymbol{0}$ Unphosphorylated PLM was estimated as the C2 signal (a, d), putative S68 PLM phosphorylation was estimated as the CP68 signal (b, e) and force as percent of a prior $109 \mathrm{mM}\left[\mathrm{K}^{+}\right]_{\mathrm{o}}$ contraction (c, f). Some error bars are obscured by the symbols.

The relation between the CP68/KF ratio and active force is shown in figure 4 . There was a highly significant negative correlation between the CP68 signal and force $\left(\mathrm{r}^{2}=0.5 ; \mathrm{p}<0.0001\right.$, ANCOVA). There was no significant difference in the slopes or intercept of the regression lines for tissues stimulated with histamine or high $\left[\mathrm{K}^{+}\right]_{\mathrm{o}}$, suggesting a simple inverse relation between the degree of forskolin-induced relaxation and the degree of S68 PLM phosphorylation.

We evaluated whether agents that increase [cGMP] also induce PLM phosphorylation. Histamine $(10 \mu M)$

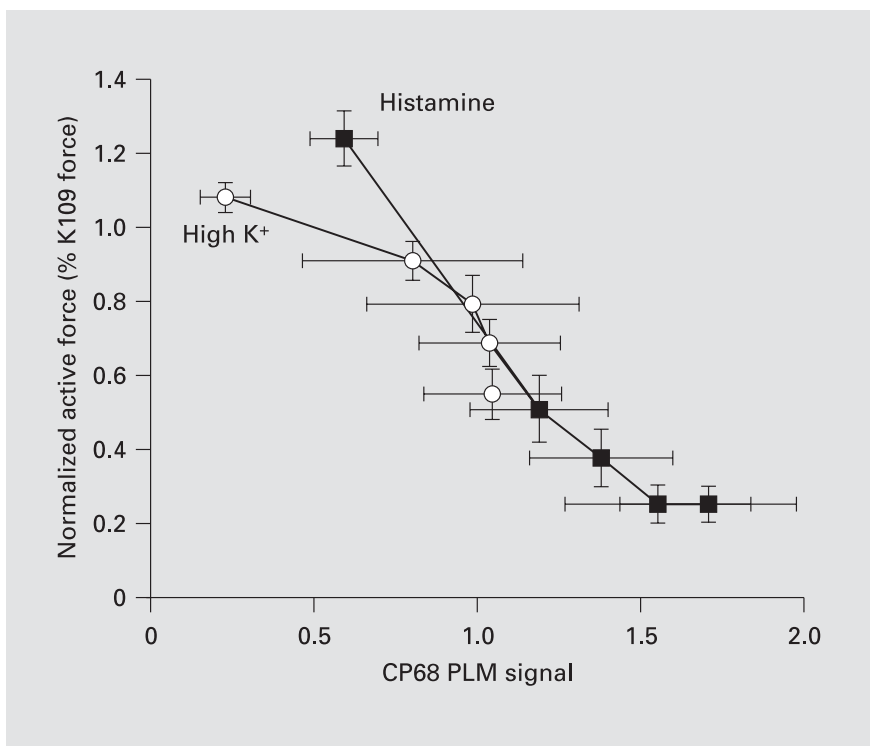

Fig. 4. Dependence of contractile force on the CP68 signal (putative S68 PLM phosphorylation). Data are replotted from figure 3. $\mathbf{\square}=$ Histamine-stimulated tissues; $\bigcirc=$ high $\left[\mathrm{K}^{+}\right]_{\mathrm{o}}$.

induced a small increase in the CP68 signal and a maximal contraction. Addition of $100 \mu M$ nitroglycerin (to increase [cGMP]) induced a relaxation without changing the CP68 signal from the values observed with histamine alone. Addition of $1 \mu M$ forskolin (to increase [cAMP]) further increased the CP68 signal.

If S68 PLM phosphorylation were to cause relaxation by increasing the activity of the Na,K-ATPase, then forskolin should reduce $\left[\mathrm{Na}^{+}\right]_{\mathrm{i}} \cdot\left[\mathrm{Na}^{+}\right]_{\mathrm{i}}$ is difficult to measure in intact smooth muscle, but can be inferred by the response to removal of extracellular $\left[\mathrm{Na}^{+}\right]\left(\left[\mathrm{Na}^{+}\right]_{0}\right)[31,32]$. If L-type $\mathrm{Ca}^{2+}$ channels are blocked, contraction induced by removal of $\left[\mathrm{Na}^{+}\right]_{0}$ should result from the increase in $\left[\mathrm{Ca}^{2+}\right]_{\mathrm{i}}$ that occurs from $\mathrm{Ca}^{2+}$ influx through reversal of the Na-Ca exchanger. If forskolin were to reduce $\left[\mathrm{Na}^{+}\right]_{\mathrm{i}}$, then there would be less $\mathrm{Na}^{+}$for the $\mathrm{Na}-\mathrm{Ca}$ exchanger, less increase in $\left[\mathrm{Ca}^{2+}\right]_{\mathrm{i}}$ and less contraction. We evaluated the effect of forskolin pretreatment on swine carotid artery contraction induced by a zero $\mathrm{Na}^{+}$saline in the presence of $10 \mu M$ diltiazem (fig. 6). Pretreatment with $1 \mu M$ forskolin for 15 min significantly reduced the zero $\mathrm{Na}^{+}$ contraction compared with a control that was not treated with forskolin. 


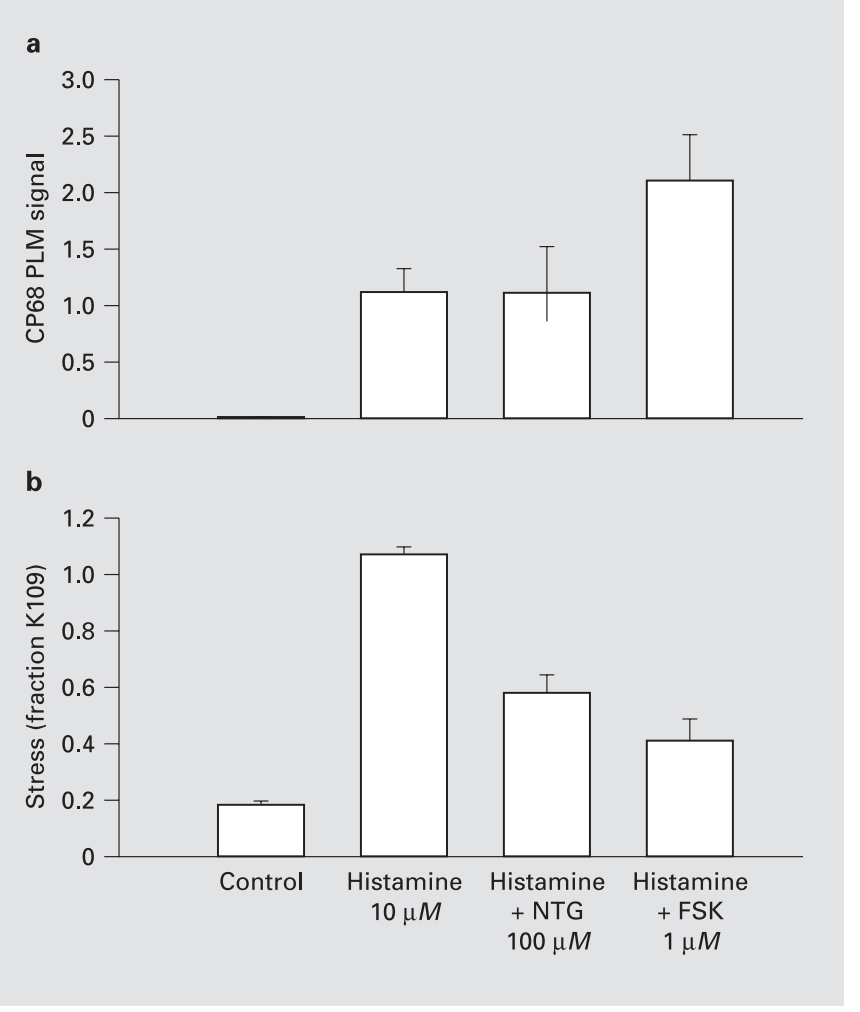

Fig. 5. Biochemical events occurring with forskolin (FSK) or nitroglycerin (NTG) induced swine carotid artery relaxation. Immuoblot intensity was normalized as described in 'Material and Methods' and is presented as mean \pm 1 SEM with $n=4-5$. Tissues were unstimulated (control), contracted with $10 \mu M$ histamine for $60 \mathrm{~min}$, contracted with $10 \mu M$ histamine for $10 \mathrm{~min}$ and relaxed by addition of $100 \mu M$ nitroglycerin for $50 \mathrm{~min}$, or contracted with $10 \mu M$ histamine for $10 \mathrm{~min}$ and relaxed by addition of $1 \mu M$ forskolin for 50 min. Putative S68 PLM phosphorylation was estimated as the CP68 signal (a) and force as percent of a prior $109 \mathrm{mM}\left[\mathrm{K}^{+}\right]_{\mathrm{o}}$ contraction $(\mathbf{b})$.

\section{Discussion}

We found PLM immunoreactivity in smooth muscle (fig. 2). These data suggest that the 16/17-kDa phosphoprotein identified in smooth muscle plasma membrane preparations [12-14] was likely PLM. We found that the CP68 PLM signal correlated with cAMP-, but not cGMPmediated relaxation (fig. 3, 5). These data suggest a potential role for S68 PLM phosphorylation in cAMP-, but not cGMP-mediated relaxation. The CP68 PLM signal was increased by histamine stimulation but not high $\left[\mathrm{K}^{+}\right]_{\mathrm{o}}$ depolarization (fig. 3), suggesting that histamine stimulation, but not high $\left[\mathrm{K}^{+}\right]_{0}$ depolarization, also increases $\mathrm{S} 68$

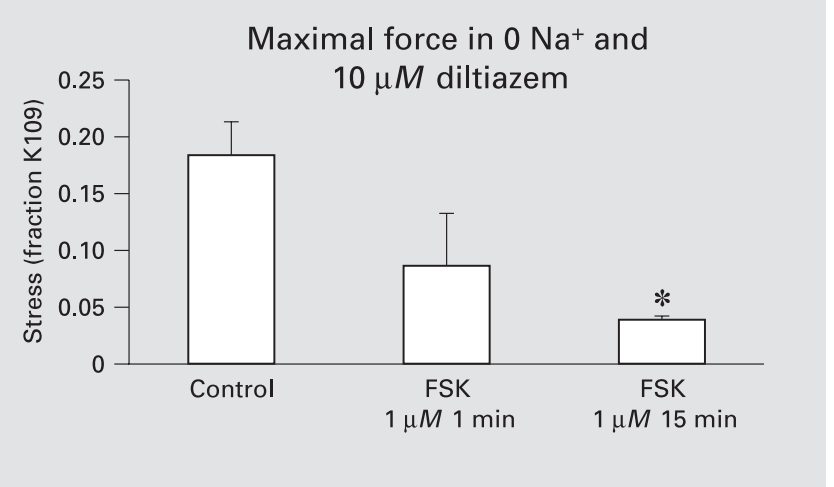

Fig. 6. Forskolin-dependent contractile response to removal of extracellular $\left[\mathrm{Na}^{+}\right]$. Four sets of tissues were incubated in $10 \mu \mathrm{M}$ diltiazem for 15 min prior to removal of $\left[\mathrm{Na}^{+}\right]_{0}$ by changing to a $\mathrm{Na}^{+}$-free PSS which had choline ${ }^{+}$substituted for $\mathrm{Na}^{+}$. Forskolin $(1 \mu M)$ was either not added (control), added $1 \mathrm{~min}$ prior to removal of $\left[\mathrm{Na}^{+}\right]_{\mathrm{o}}$ or added $15 \mathrm{~min}$ prior to removal of $\left[\mathrm{Na}^{+}\right]_{\mathrm{o}}$. The resulting peak contraction is shown as mean \pm 1 SEM and analyzed by an ANOVA with Student-Newman-Keuls testing with * indicating a significant difference compared with no forskolin. Forskolin pretreatment for 15 min significantly reduced the zero $\mathrm{Na}^{+}$contraction.

PLM phosphorylation, either via histamine-induced activation of PKC or PKA. Pretreatment with $1 \mu M$ forskolin for 15 min significantly reduced swine carotid contraction induced by zero $\left[\mathrm{Na}^{+}\right]_{0}$ (fig. 6). This result is consistent with the hypothesis that forskolin reduced $\left[\mathrm{Na}^{+}\right]_{\mathrm{i}}$.

\section{PLM Antibody Specificity}

Our results suggest that the CP68 antibody detects $\mathrm{S} 68$ PLM phosphorylation. PKA treatment of recombinant PLM increased the CP68 signal (fig. 1). Since dephosphorylated PLM did not produce a CP68 signal, we suggest that the CP68 antibody is specific to phosphorylated PLM. However, we cannot state that the CP68 antibody is absolutely specific to $\mathrm{S} 68$ because we could not make PLM that was only phosphorylated on S63 (there is no kinase that specifically phosphorylates PLM on S63).

The specificity of the $\mathrm{C} 2$ antibody could not be clearly delineated either, since PKA treatment induced only approximately $50 \%$ phosphorylation. Nevertheless, the C2 signal decreased by approximately 50\% with PKA treatment, suggesting that the $\mathrm{C} 2$ antibody is at least partially specific to dephosphorylated PLM over phosphorylated PLM. Similar results were seen in intact swine carotid: forskolin treatment increased the CP68 signal and decreased the $\mathrm{C} 2$ signal (fig. 2). We found it important to use large dilutions $(1: 10,000)$ of the $\mathrm{C} 2$ antibody to detect 
the fall in the $\mathrm{C} 2$ signal when PLM was phosphorylated. These results confirm and extend those of Silverman et al. [33] who evaluated the C2 and CP68 immunoreactivity in forskolin and phorbol ester-treated rat cardiac myocytes. Both studies agree that PKA activation leads to an increase in the CP68 signal and a decrease in the C2 signal.

Histamine alone induced a large decrease in the $\mathrm{C} 2$ signal with only a small increase in the CP68 signal (fig. 3 ). This suggests that histamine alone may have caused phosphorylation of PLM on sites other than S68. These sites may include S63 phosphorylated by PKC $[2,3]$ or other sites phosphorylated by other kinases. Supporting this contention was the finding that addition of forskolin to histamine increased in the CP68 signal without further decreases in the $\mathrm{C} 2$ signal. Perhaps forskolin-induced S68 PLM phosphorylation (detected by CP68) on PLM already phosphorylated at other sites (possibly S63) so that there was no change in the $\mathrm{C} 2$ signal. The results with high $\mathrm{K}^{+}$-depolarized tissues support this contention; there was no change in the $\mathrm{C} 2$ signal with high $\mathrm{K}^{+}$alone, consistent with a lack of PKC activation with high $\mathrm{K}^{+}$. After high $\mathrm{K}^{+}$activation, forksolin decreased the $\mathrm{C} 2$ signal and increased the CP68 signal, consistent with the C2 antibody detecting the decline in unphosphorylated PLM and CP68 detecting the S68 phosphorylation. These data suggest that forskolin can induce S68 PLM phosphorylation regardless of PLM phosphorylation at other sites.

\section{Physiology of PLM Phosphorylation in Smooth Muscle}

Addition of forskolin to high $\left[\mathrm{K}^{+}\right]_{\mathrm{o}}$ increased S68 PLM phosphorylation, but at any given [forskolin], there was less S68 PLM phosphorylation and less relaxation in tissues depolarized with high $\left[\mathrm{K}^{+}\right]_{0}$ than in tissues stimulated with histamine (fig. 3). This may be related to the increase in S68 PLM phosphorylation induced by histamine alone. There was a highly significant inverse correlation between S68 PLM phosphorylation and force (fig. 4). This suggests that S68 PLM phosphorylation could be involved in cAMP-dependent relaxation. However, such a correlation does not definitively establish PLM as a determinant of the resulting relaxation. Further experiments are planned to evaluate whether S68 PLM phosphorylation is a regulator of smooth muscle force.

We also evaluated whether cGMP-mediated relaxation involves S68 PLM phosphorylation. Many substrates for PKA are also substrates for protein kinase G. We find that nitroglycerin-induced relaxation was not associated with changes in S68 PLM phosphorylation (fig. 5). This suggests that PLM can only be involved in cAMP-mediated relaxation.

There is a physical and functional association of PLM with membrane ion transporters such as the $\mathrm{Na}, \mathrm{K}-\mathrm{ATP}$ ase $[6,7]$ and the Na-Ca exchanger (NCX1) $[8,9]$. Based on our data and these studies, we hypothesize that PLM may be involved in smooth muscle regulation via regulation of $\mathrm{Na}, \mathrm{K}$-ATPase. $\beta_{2}$-Adrenergic stimuli, presumptively via increasing [cAMP], increased Na,K-ATPase activity in smooth muscle [34]. Fay and Moore [35] found that $\beta_{2}$-adrenergic stimuli in smooth muscle reduced $\left[\mathrm{Na}^{+}\right]_{i}$, suggesting an increase in $\mathrm{Na}, \mathrm{K}-\mathrm{ATP}$ ase activity. However, Borin [36] found that cAMP increased $\left[\mathrm{Na}^{+}\right]_{\mathrm{i}}$ in isolated smooth muscle cells. Na,K-ATPase knockout mice have been made, but are lethal, with death occurring just after birth. Neonatal aortae from $\alpha_{2}-\mathrm{Na}, \mathrm{K}-\mathrm{ATPase}$ -/- mice were less sensitive to forskolin-induced relaxation when compared with $\alpha_{2}-\mathrm{Na}, \mathrm{K}-\mathrm{ATPase}+/+$ mice [37]. We also find that forskolin inhibited the swine carotid contraction induced by removal of $\left[\mathrm{Na}^{+}\right]_{0}$ (fig. 6), suggesting that forskolin reduced $\left[\mathrm{Na}^{+}\right]_{i}$, possibly by stimulation of $\mathrm{Na}, \mathrm{K}-\mathrm{ATPa} e$ activity. It must be noted that zero $\left[\mathrm{Na}^{+}\right]_{\mathrm{o}}$ studies are only suggesting that $\left[\mathrm{Na}^{+}\right]_{\mathrm{i}}$ is reduced. We plan to study more direct measures of $\mathrm{Na}, \mathrm{K}-$ ATPase activity in the future. Nevertheless, these data support the hypothesis that cAMP-mediated relaxation at least partially involves $\mathrm{Na}, \mathrm{K}-\mathrm{ATPase}$, likely by increasing its activity.

Specifically, we hypothesize that PKA-mediated phosphorylation of PLM on S68 increases the activity of $\mathrm{Na}, \mathrm{K}$-ATPase. Since Na,K-ATPase moves $3 \mathrm{Na}^{+}$outward and $2 \mathrm{~K}^{+}$inward for every ATP consumed, it will produce a small hyperpolarization from the excess outward $\mathrm{Na}^{+}$flux [for a review, see ref. 38]. This hyperpolarization reduces $\mathrm{Ca}^{2+}$ influx through L-type $\mathrm{Ca}^{2+}$ channels, and is one method whereby increases in $\mathrm{Na}, \mathrm{K}-\mathrm{ATPase}$ activity could reduce $\left[\mathrm{Ca}^{2+}\right]_{\mathrm{i}}$ and cause smooth muscle relaxation. A second mechanism is that increases in $\mathrm{Na}, \mathrm{K}-\mathrm{ATPase}$ activity, via decreases in $\left[\mathrm{Na}^{+}\right]_{\mathrm{i}}$, could also increase $\mathrm{Ca}^{2+}$ extrusion via forward $\mathrm{Na}-\mathrm{Ca}$ exchange. This would also reduce $\left[\mathrm{Ca}^{2+}\right]_{\mathrm{i}}$ and cause smooth muscle relaxation; however, it would be associated with increased $\mathrm{Ca}^{2+}$ efflux rather than the decrease in $\mathrm{Ca}^{2+}$ influx expected with hyperpolarization. We found that forskolin induced a hyperpolarization in rat tail artery [23] and a decrease in $\mathrm{Mn}^{2+}$ influx in swine carotid artery [39], suggesting that hyperpolarization may be the dominant mechanism in some smooth muscles.

PLM has a role in the regulation of cardiac contractility by $\left[\mathrm{Ca}^{2+}\right]$ as well. In cultured rat heart myocytes, the 
myocytes near an area of infarction have an abnormally blunted contractile response to extracellular $\mathrm{Ca}^{2+}\left(\left[\mathrm{Ca}^{2+}\right]_{0}\right)$ [40]. Overexpression of PLM produces myocytes with a blunted $\left[\mathrm{Ca}^{2+}\right]_{0}$ response similar to those observed after myocardial infarction [28]. Intriguingly, PLM is one of a few genes whose expression level rises after myocardial infarction [41], suggesting that PLM could be the mediator of the blunted $\left[\mathrm{Ca}^{2+}\right]_{0}$ response. If NCX1, the cardiac $\mathrm{Na}-\mathrm{Ca}$ exchanger, is over expressed in peri-infarction myocytes, a normal $\left[\mathrm{Ca}^{2+}\right]_{0}$ response is observed [42]. A unifying explanation would be that PLM inhibits NCX1. Supporting this were findings that PLM overexpression reduced currents through NCX1 and slowed the decline in $\left[\mathrm{Ca}^{2+}\right]_{\mathrm{i}}$ after the release of sarcoplasmic reticulum stores with caffeine [28]. Co-overexpression of NCX1 with PLM restored the currents and $\mathrm{Ca}^{2+}$ dynamics to normal [8]. Moreover, reduction of PLM expression using anti-sense oligonucleotides increased NCX1 currents and sped the decline in $\left[\mathrm{Ca}^{2+}\right]_{\mathrm{i}}$ after caffeine [9]. Most recently, Ahlers et al. [43] found a physical and functional interaction between PLM and NCX1 co-expressed in HEK293 cells. The importance of S68, the site of PKA phosphoryla- tion, was underscored by the finding that a phosphodeficient PLM mutant S68A lost the ability to inhibit $\mathrm{Na}-\mathrm{Ca}$ exchange despite persistent physical association.

These data demonstrate that PLM is functional and present in smooth muscle and is phosphorylated by physiologic stimuli. We propose that S68 PLM phosphorylation may have a role in cAMP-, but not cGMP-mediated smooth muscle relaxation, possibly by activation of the $\mathrm{Na}, \mathrm{K}-\mathrm{ATPase}$ activity. The data also demonstrate relative specificity for the C2 and CP68 PLM antibodies for dephosphorylated and S68 phosphorylated PLM, respectively.

\section{Acknowledgements}

Smithfield Co., Smithfield, Va., USA, donated the swine carotid arteries, and Tom Lincoln, $\mathrm{PhD}$, (University of Alabama) donated the PKA. Grants from the NIH - HL071191 (to C.R.), HL070548 (to R.M), CA082864 (to F.M.) and HL058672 (to J.C) - and the American Heart Association (Mid-Atlantic and Pennsylvania Affiliates) supported this research. We thank D.E. Lake for the help with the statistical analysis.

\section{References}

1 Palmer CJ, Scott BT, Jones LR: Purification and complete sequence determination of the major plasma membrane substrate for cAMPdependent protein kinase and protein kinase $\mathrm{C}$ in myocardium. J Biol Chem 1991;266:1112611130.

-2 Walaas SI, Czernik AJ, Olstad OK, Sletten K, Walaas O: Protein kinase $\mathrm{C}$ and cyclic AMPdependent protein kinase phosphorylate phospholemman, an insulin and adrenaline-regulated membrane phosphoprotein, at specific sites in the carboxy terminal domain. Biochem J 1994;304:635-640.

- 3 Mounsey JP, Lu KP, Patel MK, Chen ZH, Horne LT, John JE 3rd, Means AR, Jones LR, Moorman JR: Modulation of Xenopus oocyteexpressed phospholemman-induced ion currents by co-expression of protein kinases. Biochim Biophys Acta 1999;1451:305-318.

-4 Moorman JR, Ackerman SJ, Kowdley GC, Griffin MP, Mounsey JP, Chen Z, Cala SE, O'Brian JJ, Szabo G, Jones LR: Unitary anion currents through phospholemman channel molecules. Nature 1995;377:737-740.

-5 Morales-Mulia M, Pasantes-Morales H, Moran J: Volume sensitive efflux of taurine in HEK293 cells overexpressing phospholemman. Biochim Biophys Acta 2000;1496:252260
-6 Crambert G, Fuzesi M, Garty H, Karlish S, Geering K: Phospholemman (FXYD1) associates with $\mathrm{Na}, \mathrm{K}-\mathrm{ATP}$ ase and regulates its transport properties. Proc Natl Acad Sci USA 2002; 99:11476-11481.

-7 Feschenko MS, Donnet C, Wetzel RK, Asinovski NK, Jones LR, Sweadner KJ: Phospholemman, as single-span membrane protein, is an accessory protein of the Na,K-ATPase in cerebellum and choroid plexus. J Neurosci 2003;23:2161-2169

8 Zhang XQ, Quershi A, Song J, Carl LL, Tian R, Stahl RC, Carey DJ, Rothblum LI, Cheung JY: Phospholemman modulates $\mathrm{Na}^{+} / \mathrm{Ca}^{2+}$ exchange in adult rat myocytes. Am J Physiol Cell Physiol 2003;284:H225-H233.

-9 Mirza MA, Zhang XQ, Ahlers BA, Qureshi A, Carl LL, Song J, Tucker AL, Mounsey JP, Moorman JR, Rothblum LI, Zhang TS, Cheung JY: Effects of phospholemman downregulation on contractility and $\left[\mathrm{Ca}^{2+}\right]$ (i) transients in adult rat cardiac myocytes. Am J Physiol Heart Circ Physiol 2004;286:H1322-H1330.

$\checkmark 10$ Sweadner KJ, Rael E: The FXYD gene family of small ion transport regulators or channels: cDNA sequence, protein signature sequence, and expression. Genomics 2000;68:41-56.

11 Mercer RW, Biemesderfer D, Bliss DP Jr, Collins JH, Forbush B 3rd: Molecular cloning and immunological characterization of the gamma polypeptide, a small protein associated with the Na,K-ATPase. J Cell Biol 1993;121:579-586.
12 Boulanger-Saunier C, Kattenburg DM, Stoclet JC: Cyclic AMP-dependent phosphorylation of a $16 \mathrm{kDa}$ protein in a plasma membraneenriched fraction of rat aortic myocytes. FEBS Lett 1985;193:283-288

13 Boulanger-Saunier C, Stoclet JC: A 16 kDa protein substrate for protein kinase $\mathrm{C}$ and its phosphorylation upon stimulation with vasopressin receptors in rat aortic myocytes. Biochem Biophys Res Commun 1987;143:517521.

14 Sarcevic B, Brookes V, Martin TJ, Kemp BE, Robinson PJ: Atrial natriuretic peptide-dependent phosphorylation of smooth muscle cell particulate fraction proteins is mediated by cGMP-dependent protein kinase. J Biol Chem 1989;264:20648-20654.

15 Horowitz A, Menice CB, Laporte R, Morgan KG: Mechanisms of smooth muscle contraction. Physiol Rev 1996;76:967-1003.

16 Hai CM, Murphy RA: $\mathrm{Ca}^{2+}$, crossbridge phosphorylation, and contraction. Annu Rev Physiol 1989;51:285-298.

17 Rembold CM: Relaxation, $\left[\mathrm{Ca}^{2+}\right]_{i}$, and the latch-bridge hypothesis in swine arterial smooth muscle. Am J Physiol Cell Physiol 1991;261:C41-C50.

18 Gerthoffer WT, Murphy RA: $\mathrm{Ca}^{2+}$, myosin phosphorylation, and relaxation of arterial smooth muscle. Am J Physiol 1983;245:C271C277.

Rembold/Ripley/Meeks/Geddis/Kutchai/ Marassi/Cheung/Moorman 
19 Wingard CJ, Murphy RA: Inhibition of $\mathrm{Ca}^{2+}$ dependent contraction in swine carotid artery by myosin kinase inhibitors. Gen Pharmacol 1999;32:483-494.

20 Kume H, Mikawa K, Takagi K, Kotlikoff MI Role of $\mathrm{G}$ proteins and $\mathrm{K}_{\mathrm{Ca}}$ channels in the muscarinic and $\beta$-adrenergic regulation of airway smooth muscle. Am J Physiol Lung Cell Mol Physiol 1995;268:L221-L229.

21 Lincoln TM, Cornwell TL, Komalavilas P, MacMillan-Crow LA, Boerth NJ: The nitric oxide-cyclic GMP signaling system; in Barany M (ed): Biochemistry of Smooth Muscle Contraction. San Diego, Academic Press, 1996, pp 257-268.

22 Rembold CM: Electromechanical and pharmacomechanical coupling; in Barany $\mathrm{M}$ (ed): Biochemistry of Smooth Muscle Contraction. San Diego, Academic Press, 1996, pp 227239.

-23 Rembold CM, Chen XL: Mechanisms responsible for forskolin-induced relaxation of rat tail artery. Hypertension 1998;31:872-877.

24 Knot HJ, Brayden JE, Nelson MT: Calcium channels and potassium channels; in Barany $\mathrm{M}$ (ed): Biochemistry of Smooth Muscle Contraction. San Diego, Academic Press, 1996, pp 203-219.

25 Raeymaekers L, Wuytack F: Calcium pumps; in Barany M (ed): Biochemistry of Smooth Muscle Contraction. San Diego, Academic Press, 1996, pp 241-253.

-26 Rembold CM, O’Connor MJ, Clarkson M, Wardle RL, Murphy RA: HSP20 phosphorylation in nitroglycerin- and forskolin-induced sustained reductions in swine carotid media tone. J Appl Physiol 2001;91:1460-1466.
27 Rembold CM, Murphy RA: Myoplasmic $\left[\mathrm{Ca}^{2+}\right]$ determines myosin phosphorylation in agonist-stimulated swine arterial smooth muscle. Circ Res 1988;63:593-603.

28 Song J, Zhang XQ, Carl LL, Qureshi A, Rothblum LI, Cheung JY: Overexpression of phospholemman alters contractility and $[\mathrm{Ca}(2+)](\mathrm{i})$ transients in adult rat myocytes. Am J Physiol Heart Circ Physiol 2002;283:H576-H583.

29 Crowell KJ, Franzin CM, Koltay A, Lee S, Lucchese AM, Snyder BC, Marassi FM: Expression and characterization of the FXYD ion transport regulators for NMR structural studies in lipid miscelles and lipid bilayers. Biochim Biophys Acta 2003;1645:15-21.

30 Jones LR: Rapid preparation of canine cardiac sarcolemmal vesicles by sucrose flotation. Methods Enzymol 1988; 157:85-91.

31 Rembold CM, Richard HL, Chen XL: $\mathrm{Na}^{+}$ $\mathrm{Ca}^{2+}$ exchange, myoplasmic $\left[\mathrm{Ca}^{2+}\right]$, and contraction of arterial smooth muscle. Hypertension 1992;19:308-313.

32 Rembold CM, Chen XL: The buffer barrier hypothesis, $\left[\mathrm{Ca}^{2+}\right]_{\mathrm{i}}$ homogeneity, and sarcoplasmic reticulum function in swine carotid artery. J Physiol 1998;513:477-492.

33 Silverman BD, Fuller W, Eaton P, Deng JL, Moorman JR, Cheung JY, James AF, Shattock MJ: Serine 68 phosphorylation of phospholemman: acute isoform-specific activation of cardiac Na/K ATPase. Cardiovasc Res 2005;65: 93-103.

34 Limas CJ, Cohn JN: Stimulation of vascular smooth muscle sodium potassium adenotriphosphatase by vasodilators. Circ Res 1974; 35:601-607.

>35 Moore EDW, Fay FS: Isoproterenol stimulates rapid extrusion of sodium from isolated smooth muscle cells. Proc Natl Acad Sci USA 1993;90:8058-8062.
36 Borin ML: cAMP evokes a rise in intracellular $\mathrm{Na}^{+}$mediated by $\mathrm{Na}^{+}$pump inhibition in rat aortic smooth muscle cells. Am J Physiol Cell Physiol 1995;269:C884-C891.

37 Shelly DA, He S, Moseley A, Weber C, Stegemeyer M, Lynch RM, Lingrel J, Paul RJ: The $\mathrm{Na}^{+}$-pump alpha2-isoform specifically couples to contractility in vascular smooth muscle: evidence from gene targeted mice. Am J Physiol Cell Physiol 2004;286:C813-C820.

38 Rose AM, Valdes R: Understanding the sodium pump and its relevance to disease. Clin Chem 1994;40:1674-1685.

39 Chen XL, Rembold CM: Cyclic nucleotide dependent regulation of $\mathrm{Mn}^{2+}$ influx, $\left[\mathrm{Ca}^{2+}\right]_{i}$, and arterial smooth muscle relaxation. Am J Physiol Cell Physiol 1992;263:C468-C473.

40 Zhang XQ, Ng YC, Moore RL, Musch TI, Cheung JY: In situ SR function in postinfarction myocytes. J Appl Physiol 1999;87:21432150.

41 Sehl PD, Tai JT, Hillan KJ, Brown LA, Goddard A, Yang R, Jin H, Lowe DG: Application of cDNA microarrays in determining molecular phenotype in cardiac growth, development, and response to injury. Circulation 2000;101: 1990-1999.

42 Zhang XQ, Song J, Quershi A, Rothblum LI, Carl LL, Tian R, Cheung JY: Rescue of contractile abnormalities by $\mathrm{Na}^{+} / \mathrm{Ca}^{2+}$ exchanger overproduction in postinfarction rat myocytes. J Appl Physiol 2002;93:1925-1931.

43 Ahlers BA, Zhang XQ, Moorman JR, Rothblum LI, Carl LL, Song J, Wang J, Geddis LM, Tucker AL, Mounsey JP, Cheung JY: Identification of an endogenous inhibitor of the $\mathrm{Na}^{+}$/ $\mathrm{Ca}^{+}$exchanger: phospholemman. J Biol Chem, in press. 